\title{
S.P.G. DOCUMENTARY MATERIAL ON AUSTRALIA, 1788-1900
}

\author{
BY SAMUEL CLYDE MCCULLOCH
}

A Native of Australia, Dr. McCulloch completed his undergraduate and graduate work in the United States, and became an American citizen. His doctoral dissertation was a study of the life and times of Dr. Thomas Bray (I658-I730), the founder of the S.P.G. He is Associate Professor of History and Assistant Dean of the College of Arts and Sciences at Rutgers, and his specialty is British Empire History. Last year he spent at the University of Sydney, Australia, as a Fulbright Research Fellow.

$\mathrm{F}$ IVE YEARS AGO the Library decided to microfilm all documents relating to Australia up to I900 that are deposited in the archives of the Society for the Propagation of the Gospel in Foreign Parts, better known as the S.P.G., and invited the Library of the University of California, Los Angeles, to sponsor the project jointly. The result is sixty-four reels of significant and valuable material. After the filming was completed the Librarians at Rutgers and U.C.L.A. very generously donated the negative to the Library of Congress, thus making four depositories for this material, three in the United States, and the original at S.P.G. House, I 5 Tufton Street, London.

The S.P.G. is one of the oldest and greatest of Anglican missionary societies, dating back to I $70{ }^{1}{ }^{1}$ Besides propagating the gospel, the Society strove to better education, found libraries, and promote prison reform. It contributed to making the Anglo-Saxon world more humane, to stimulating intellectual development, and certainly to ameliorating some of the more brutal aspects of imperialism. ${ }^{2}$ Between I $70 \mathrm{I}$ and I 785, the S.P.G. maintained in British North America alone some 353 missionaries, and numerous schoolmasters, medical men, and libraries. ${ }^{3}$ The letters and semi-

\footnotetext{
${ }^{1}$ For accounts of the S.P.G. and its work in Australia see C. F. Pascoe, Two Hundred Years of the S.P.G., 2 vols. (London, 1901), Work in the Colonies: Some Account of the Missionary Operations of the Church of England in Connection with the S.P.G. (London, 1865), and H. P. Thompson, Into All Lands: The History of the Society for the Propagation of the Gospel in Foreign Parts, $1701-1950$ (London, 1951).

${ }^{2}$ Frank J. Klingberg, Anglican Humanitarianism in Colonial Nea York (Philadelphia, 1940), 4 .

${ }^{3}$ Frank J. Klingberg, ed., Codrington Chronicle, An Experiment in Anglican Altruism on a Barbados Plantation, $7_{70-18} 34$ (Berkeley and Los Angeles, 1949), 7.
} 
annual reports to and from America, deposited in the vast archives of the S.P.G., were transcribed many years ago and later microfilmed (in I 928-29) by the Library of Congress. Professor Frank J. Klingberg of the University of California, Los Angeles, mined mountains of these I 8th century manuscripts for the historical veins of gold that lay within.

These missionaries, wrote Professor Klingberg, were "constantly advised from London and asked to carry out definite policies as a group and as individuals. Often graduates of Oxford, Cambridge, Trinity College (Dublin), Edinburgh and Glasgow, as well as of American colleges, they reported with skill worthy of a Swift, a Defoe, or a Fielding, sketching the colonial scene in unforgettable terms." Professor Klingberg's great contribution was to organize and then to interpret these materials from the social, economic, political, and cultural points of view. As unofficial reporters of colonial society these missionaries provided a great body of nongovernmental materials.

Almost fifty years ago, in his presidential address before the American Historical Association, J. Franklin Jameson pointed out the significance of religious records for historical purposes. ${ }^{5}$ In his opinion, their importance as sources for modern history was perhaps greater than for the mediaeval period. The records of the English missionary societies were on a broad front, world-wide in fact. Professor Charles M. Andrews of Yale recognized that cohorts of workers were needed for such a vineyard of rich documents, and he wanted the material incorporated as a major theme in the great story of Britain's expansion. Even he was unaware of the enormous extent and quality of these ecclesiastical records. In his last years he envisioned that Professor Klingberg and his students (of which this present writer is one), and their students of the third generation, would complete the story of the expansion of English culture over large areas of the world. The two or three million pages of the records for the igth century have barely been touched. Andrews' dream was not that of a new and separate religious history, but that this story of human endeavor would be incorporated into the his-

\footnotetext{
${ }^{4}$ Frank J. Klingberg, "Contributions of the S.P.G. to the American Way of Life," Historical Magazine of the Protestant Episcopal Church, XII (1943), 22 I.

5 "The American Acta Sanctorum," American Historical Review, XIII (1908), 286302.
} 
torian's general account of the development of every country the missionary visited.

The i 9 th century records of the S.P.G. have really never been used, although this Society ranks almost equally with the London Missionary Society and the Church Missionary Society. In the settlement and development of Australia the S.P.G. gave worthy support. Between I793, only five years after the First Fleet under Captain Arthur Phillip dropped anchor in Sydney Harbor, and I 900 , the Society helped to support 435 missionaries, expending over a quarter of a million pounds sterling to do this $\left(\mathfrak{E}_{253} 53,59\right) .{ }^{6}$ The letters and reports which travelled between Australia and England have been preserved in the S.P.G. archives, and are to be found among the sixty-four reels of microfilm now in the Rutgers Library. They provide invaluable material for the general historian, indispensable material for the writer of Australian religious history.

The material may be classified as follows:

A. Letters and Reports of the Missionaries in Australia

I. The C-Manuscripts, Original Letters, I 789-I 850, 5 reels.

2. The D-Manuscripts, Originals and Copies of Letters, I 85 r-I 900 , I I I $/ 2$ reels.

3. The E-Manuscripts, Copies of Reports from Missionaries, I 845 -I 900,3 I $/ 2$ reels.

4. The F-Manuscripts, Copies of Letters sent by the S.P.G. to Australian Dioceses, I 837-I 900, I 1/2 reels.

B. Journals and Reports of the S.P.G.

I. Journals, I 783-I 90I, I I I/2 reels.

2. Minutes of the Standing Committee, I833-1900, I 4 reels.

3. Annual Reports, I 783-1900, I61/2 reels.

\section{The C-Manuscripts}

Between I 788 and I850, the S.P.G. was active in supporting many missionaries. The word missionary is always an elastic one, denoting any minister receiving support from the Society. Thus the chaplain, the Rev. Richard Johnson, who accompanied the First Fleet to Sydney, the Rev. Samuel Marsden who succeeded him, Archdeacon Scott, and William Grant Broughton, first bishop

${ }^{6}$ Pascoe, Two Hundred Years of S.P.G., I, $466-67$. 
of Australia, all were correspondents since they were supported by the S.P.G. Of these Bishop Broughton is the most interesting. There are over I 50 letters written by him, not only to the S.P.G. and Australian clergy, but to governors and lesser officials, and there are over IOo letters written to him.

Broughton came out from England to Sydney as archdeacon in I 829, and immediately became a member of the Legislative Council and of the Executive Council. In 1836 he became the first Anglican bishop of Australia, and while travelling in his diocese fulfilling his episcopal duties he proved to be a shrewd observer of the secular scene. In 1838 , after a visit to Melbourne, he correctly predicted that the town would "become very speedily an opulent and important scene of business." When the dioceses of Melbourne, Adelaide, Newcastle, and Sydney were created in I 847 , he became bishop of the last named. He died in 1853 .

At all times he was fearless when he felt his course was right, and he was not afraid to criticize even the governor. Shortly after Sir George Gipps, Governor of New South Wales from i 838 to r 846 , reached Sydney, he reported to the Colonial Office that there were enough ministers in the colony. ${ }^{8}$ Broughton was furious, claiming that Gipps had only been in the colony nine months when he made the statement, and that there was no real basis for making it. If Gipps had wanted to know the true state of affairs in the Church he should have asked Broughton! ${ }^{9}$ Gipps admitted making the statement early in his official residence, but claimed that he had backed up his statement at a later date. ${ }^{10}$ Broughton refused to let the matter drop, and pursued the issue until it was settled in his favor. ${ }^{11}$

Unfortunately the caliber of the earlier missionaries supported by the S.P.G. was not up to the standard of their successors as the following section from a letter of application dated May I6, I 828, indicates:

${ }^{7}$ Broughton to Campbell, May 22, i 838 , C-MSS, Reel 1 .

$8 \mathrm{~A}$ number of the letters from the S.P.G. to Broughton after 1837 are in the F-Manuscripts, as for example this one, of August 28, 1839, informing him that the Colonial Office had just informed them of the Gipps despatch.

${ }^{9}$ Broughton to Gipps, April 1o, 1840, C-MSS, Reel I.

${ }^{10}$ Gipps to Broughton, April 30, I 840, C-MSS, Reel I.

${ }_{11}$ Broughton to Hawkins, March 20, I84 I, C-MSS, Reel 2. 
"I beg to be permitted to state that I am now in my forty-first year, and in consequence of the heavy pressures of a large family (two sons and seven daughters, between the ages of seventeen years and twelve months) combined with very faint hopes of success in my profession in this country, am anxious to find a field for my humble exertions in the colonies attended to, ..."12

By about I 840 the caliber of the clergy had much improved. The hundreds of letters between 1788 and I 850 reveal many an interesting sidelight on pioneering days. Occasionally extracts from the journal of a minister were sent home to the S.P.G. For example, there is the journal of the Rev. W. H. Coombs, who had a church near Gawler, South Australia. On January 3, I847, he could not conceal his amazement at the good attendance at church in view of the terrible state of nearby roads:

"There is all the difference between the fine turnpike roads of England, without any obstruction, and the rough track made here and there through the Australian forest, beset with tree trunks, stones \& gulleys worn by the rains. Not to speak of injury to a vehicle, there is of course great risk incurred of life and $\operatorname{limb}$ - so that the utmost care and caution are required."13

Another interesting journal was that of the Rev. W. J. Woodcock of Adelaide, South Australia. ${ }^{14}$

Besides journals, extracts from newspapers describing major events, printed reports of societies and church organizations, and even government statistical pamphlets, for example, "Statistics of South Australia, I $845,{ }^{15}$ were often enclosed with the letters to the S.P.G. The reports from aboriginal mission stations showed that slow progress was being made among the primitive tribes.

\section{The D-Manuscripts}

In these letters from Australia, I 85 I-I900, there are more originals than copies, and they come almost exclusively from the bishops of the various dioceses. The bishops evidently did all the letter writing to the Society, the quarterly reports (E-Manuscripts) from the missionaries being presumably satisfactory to the Society. Enclosures accompanying the letters from the bishops are sometimes more interesting and informative than the letters themselves. Many a detail on diocesan affairs was enclosed: printed reports and im${ }^{12}$ Chester to Huskisson, May I6, 1828, C-MSS, Reel I.

${ }_{13}$ C-MSS, Reel 5.

${ }^{14}$ Ibid., Reel 4 .

${ }^{15}$ Ibid., Reel 4 . 
portant statistical information concerning the work and salary of the clergy; occasionally letters from ministers to their bishops were included. There were also minutes of diocesan standing committees, and reports from church affiliated schools. A few letters from New Zealand dioceses are found among the D-Manuscripts.

Odd tidbits of information can be gleaned from some of the enclosures. For example, a letter from the London office of the $\mathrm{Ca}$ nadian Pacific Railway, dated June IO, I 893, advises missionaries who wish to travel to Australia (and New Zealand and the Sandwich Islands) that the total fare from Liverpool to Australia would be E60-I 6-4, via Vancouver. ${ }^{16}$ Another small item was a printed copy of "An Act To provide a Constitution for the Church of England Grammar School at Geelong" brought before the I86I legislative session in Melbourne. ${ }^{17}$ This school happens to be this present writer's Australian alma mater.

The wealth of this material sent to London between $185 \mathrm{I}$ and I 900 reveals the breadth of the Society's interests, and testifies that the S.P.G. was indispensable to the development and expansion of the Anglican Church in Australia.

\section{The E-Manuscripts}

These mostly comprise copies of the annual reports, I 845-I900, sent to the S.P.G. from those men it supported in all parts of Australia. The format of the report was changed from time to time; but fundamentally it included some twelve printed questions which had to be answered. These sought statistical data about the religious life of those in the missionaries' charge. The last question never changed: "Has anything prevented the transmission of your Quarterly Reports during the past year?"

These quarterly reports are included in the E-Manuscripts, and they varied in quantity and quality. In general a missionary sent a quarterly report only if in his opinion there was information worth sending. He included comments on the sheep industry, the aborigines, general economic problems, the geography of the land, and other non-religious facts that caught his notice.

Occasionally a special questionnaire was sent out to all missionaries by the Society. For example, a questionnaire dated September 30, ${ }^{16}$ D-MSS, Reel 16.

${ }^{17}$ Ibid., Reel 18. 
I 845 was filled out by all Australian missionaries. Some twentythree questions were asked, inquiring about the number of houses in the area, the gross population, the increase of population, the chief occupations of the inhabitants, whether the population tended to be migratory, etc. Question number eight was of particular value to historians: "Give such information as you may possess, whether from public documents or other sources, as to the progress of the town and neighbourhood in improvement as to trade and commerce, agriculture, or other sources of wealth?" ${ }^{18}$

\section{The F-Manuscripts}

As soon as the first bishopric was established in I 836, the S.P.G. began corresponding with Bishop Broughton. The F-MSS are copies of letters sent by the S.P.G. to the various bishops of each diocese, dating from the foundation of the respective dioceses. By I 880 there were twelve. The letters were strictly religious and shed light only on the religious history of Australia.

\section{The S.P.G. Journals}

These are the minutes, written out in long hand, of all the general meetings of the Society. Anywhere from five to twelve were called in a year, and matters of major policy were decided upon. Since it was not possible to separate Australian affairs from the general body of material, these Journals present the complete picture of the Society in action. All motions were recorded and Committee reports were acted upon. The Society's decisions on letters coming from Australia are of particular interest. For example, the Rev. Richard Johnson, first minister in the colony of New South Wales, wrote a letter on March 21, I792 (which is to be found in the C-MSS, Reel I) requesting aid for schoolmasters, books, and missionaries for the aborigines. This letter was read at the March I 5 , I 793, meeting of the Society, and the Journals record that it was decided to "give an annual allowance of $£$ io each to any number of school masters and mistresses not exceeding four, . . ."19

The Journals are useful for identifying letters sent from Australia. For example, a long letter by Johnson written in 1798 is faded and difficult to read, and the exact date cannot be made out. In it he men-

${ }^{18}$ E-MSS, Reel Io.

19 S.P.G. Journal, Vol. 26, 124-28. 
tions a rather elaborate plan for a school, as well as pleading for spelling books. ${ }^{20}$ The Journals for October I I, I 799, record a letter of August 3 I, I 798, from Johnson, and briefly summarize the contents. ${ }^{21}$ It is thus safe to assign this date to the letter.

As the I 9 th century progressed and the work of the Society spread over the globe, the meetings became longer and more complicated, and it was necessary to rely on the work of the Standing Committee.

\section{Mimutes of the Standing Committee}

From I 833 on, the Standing Committee assumed the major burden of administrative responsibilities. It sifted, organized, and clarified requests made to the Society, and suggested appropriate recommendations. Furthermore, it formulated principles governing basic decisions.

Around I 844, sub-committees for Australasia, India, and North America were appointed, but they soon became defunct. They were revived in 1879 , with the one for America expanded to read "America and the West Indies." A sub-committee for Africa was added. But no matter from which colony the letters came, the majority contained financial requests. The minutes now became much fuller. As one studies these minutes from 1833 to r 900 , one cannot fail to be impressed by the global nature of the activities undertaken by the S.P.G.

\section{The Annual Reports}

These were printed every year, and distributed in book form. Each issue contained a copy of the annual sermon preached before the Society, an abstract of the charter, the Abstract of Proceedings (this was distributed separately to the thousands of parishes of England and Wales), and a list of the members.

An outstanding minister was always chosen each year to preach the annual sermon. Professor Klingberg, who studied these sermons for the I 8th century, has pointed out their historical importance. They contain, he writes

${ }^{20}$ Johnson to S.P.G., C-MSS, Reel I. This and other letters were not available to Dr. George Mackaness in his excellent two part monograph Some Letters of Rev. Richard Johnson, B.A., First Chaplain of New South Wales (Sydney, 1954). Dr. Mackaness does print the précis of the letter from the S.P.G. Journal, see Part ii, 28.

21 Pages 440-41. 
"... a mine of information about the intellectual and philosophical conceptions of the time. The attempts to thresh out a proper philosophy for the Society to cover the conflicting interests, in the colonies and at home, of the British trader, the white settler, the imported Negro, and the endangered Indian, can be distilled from the sermons, a battle forum for the reconciliation of Christian idealism, imperial interests, and business profits." ${ }^{22}$

No attempt has yet been made to study and analyze the I 9 th century sermons, so that very profitable and fruitful research awaits any mature scholar willing to invest his time.

The Abstract of Proceedings each year invariably provides a detailed picture of global responsibilities. At the center, in London, sat the executive body, sending orders and receiving reports from all parts of the British Empire. These reports, particularly those from Australia, demonstrate the diverse nature of the work. All the important letters, decisions, and orders were summarized in the $A b$ stracts. In I 826, the title of the Abstract was changed to Report of the Proceedings of the Society, and there was added "Lists of the Society's missionaries, catechists, and schoolmasters; the incorporated and associated members; and the diocesan and district committees." ${ }^{23}$ The Reports continued to be even more informative because they added useful appendices in which long letters were quoted verbatim, and lists of statistical material were printed in full. The Treasurer's reports, for example, printed receipts from the various dioceses throughout the world.

It was not until 1836 that Australia was first mentioned in the Reports. ${ }^{24}$ However, mention was made every year from then on, and in 1838 the following statement appeared: "In no branch of the Society's recent labours have the public manifested a livelier interest, and in none has their success been more encouraging, than in the diocese of AUSTRALIA." ${ }^{25}$ In the 1840 's a growing concern was exhibited for the spiritual needs of the squatters living outside the boundaries of location. "The state of the people in these districts," stated the Report of $\mathrm{I} 849$, "in respect to religious ordinances is most deplorable, and is now occupying the serious attention of the Church at Sydney; ..."26 The work in distant, sparsely populated Australia

\footnotetext{
${ }^{22}$ Klingberg, Anglican Humanitarianism in Colonial New York, 8.

${ }^{23}$ See Reel 3 . ${ }^{24}$ Report of the Proceedings (of 1836 ), 45.

${ }^{25}$ Ibid. (for 1838 ), 48 .

${ }^{26}$ Report of the Incorporated Society... for the Year 1849 (London, I849), clxi.
} 
was of as much concern to the S.P.G. as the work in closer, thickly populated parts of the British Empire.

From 1870 on the Reports are much fuller, and the Treasurer's accounts particularly significant.

Not only to the student of Australian history, but to the student of British Empire history in general, will these archival materials of the S.P.G. pay ample dividends from exhaustive investigation. Americans will be reminded of their own problem of evolving a distinct national pattern from European backgrounds. Yet it is clear from these records, as it is equally clear from other records, that she had problems peculiar to herself - a geographical situation in a far corner of the world, convict beginnings, a small population, an early economy that rode on "the sheep's back," a Far East that even in the I 9 th century was a Near North, great areas of low fertility producing a large degree of government action-these are some of the complications.

The discovery and intelligent utilization of new source materials inevitably means a fresh construction of the past. The S.P.G. materials reveal the frontier problem of intellectual poverty in all its ramifications. As best they could the missionaries tried to remedy the colonial poverty of mind and soul. The spiritual and intellectual needs of the Australian settlers were clearly revealed in report after report. The missionary did what he could to remedy the situation. At the same time he described, quite unofficially, the whole Australian scene and society.

Finally, the humanitarian influence generated by the S.P.G. was considerable. Organized Christianity has always been a great humanitarian force. Professor Klingberg has stated the case quite clearly and simply:

"Looking about over the field of casualties in history, we find here and there the man who has loved his fellow man of whatever origin and tradition and who has a vision that the world can be made more humane, more beautiful, more livable, and that the general welfare, the health and happiness of all of its inhabitants may be increased. Such as these were the men who founded the S.P.G. and who, through two and a half centuries, have worked for Christian brotherhood."27

${ }^{27}$ Klingberg, Codrington Chronicle, 12. 